teeth may persist unaltered, or little changed, for long periods.

(c) The evolution of such characters as the number of crests on a molar tooth is independent of the evolution of other characters of the tooth, such as the height of the crest.

(d) New progressive stocks arise from a point only a little above the base of the parent stock.

(e) Two stocks which separate from one another may differ very greatly indeed in the rate at which evolutionary changes take place in them.

( $f$ ) Progressive stock and parent stock may continue to live side by side, so that their remains may be buried in the same bed.

(g) The evolution of the Proboscidea has been a rapid process in comparison with that of horses or camels.

(h) The extinction of sub-families of Proboscidea occurred at all geological periods, twelve sub-families living on into Pleistocene times, four-two mastodons in America and two elephants-surviving to Recent time, two only still living.

The history of the elephants has thus been more completely illustrated than that of any other mammalian order, because in other cases no man has had at his command resources which enabled him to bring together in one place so much material, to have this material prepared and illustrated, to allot special points to able collaborators for further investigation, to have published papers sought for, translated and abstracted, and the notes of many years work kept in order by a most able secretary. If these conditions could be met, it is probable that many other mammalian orders and sub-orders would yield the details of an even more complete story, now existing frag. mentarily in scattered publications.

It is perhaps useful, because of its great importance to archæologists, to direct attention to the fact that a South American mastodon, Cuvieronius postremus, has been found in Ecuador in association with human artefacts which are only $1,600-1,800$ years old.

D. M. S. WATSON.

\section{THE TRAINING OF A REGIONAL PLANNER}

Regional Planning

An Outline of the Scientific Data relating to Planning in Great Britain. By L. B. Escritt. Pp. 264. (London : George Allen and Unwin, Ltd., 1943.) 12s. 6d. net.

$\mathrm{T}$ $\mathrm{HE}$ author of this handbook considers that regional planning is "a real study of growing importance", and that in the training of those who will undertake such planning more studies are involved than engineering and architecture. He shows the relevance of geology, the study of soils and soil surveys, of agriculture and land utilization, and a wide range of other subjects. In the space of little more than 250 pages, he has endeavoured to demonstrate the ways in which a knowledge of these subjects can be applied to problems of regional planning. $\mathrm{He}$ has written, generally, for the uninitiated, and has not assumed much preliminary training in any of these subjects.

The book "is addressed in particular to town planning, engineering and architectural students", but it is hoped that it will also be of interest to local government administrative officers. It may perhaps be hoped that no students of regional planning will confine their knowledge, for example, of geology, to the brief summary given in this volume: the useful lists of references to general literature and to publications specially dealing with planning will be a stimulus to much wider reading. But apart from the student aiming at professional qualifications, it may be sug. gested that many non-technical members of planning committees, reconstruction associations and similar bodies will find much in this volume to interest them.

An introductory chapter is followed by an attractive account of regional surveying, a subject in which Mr. Escritt evidently takes a keen interest. He makes frequent reference to the "Atlas of Croydon" and to the regional survey on which it was based : several illustrations reproduced here have been derived from that source. He strongly urges the need of such surveys as a basis for post-war planning.

In the fourth chapter Mr. Escritt discusses the education of the planner. He points out that the Scott Report expressed some dissatisfaction with the training of planners, and put forward the view that many employed as town planners are inadequately trained in the broader aspects of their work.

Mr. Escritt makes interesting comments on the syllabus prepared for the Town Planning Institute examination, and notes that at present "all universities that provide courses of study in town planning treat planning as a section of architecture, or include it as part of the work of an architectural department". He puts forward tentatively a scheme of study for those who enter the profession of planner via the universities. He suggests that this course should include work in geology, agriculture (including soil survey and forestry), economics, engineering (with some mathematics, physics, surveying, municipal engineering), architecture, regional surveying and planning. Obviously, a course designed to cover such a wide range of studies would need to be of longer duration than most degree courses, while the provision of a unified scheme of instruction in such a field would present problems of great difficulty. It may be wondered whether the training of regional planners would not be more satisfactorily approached by way of certain existing degree courses, with subsequent postgraduate instruction in those subjects which are not represented in the curriculum for the degree. Certain people would thus approach the problem with a training in engineering or architecture, others with a more general background of science or geography. For some types of regional planning it is likely that an honours course in geography, including surveying and some geology, would provide a better training in the broader aspects of the problem. Indeed, many will think that it is preferable for undergraduates to follow such courses before embarking on vocational training. If we are to have a body of professional planners, it may be most desirable to give only sufficient technical training to enable them to know which experts should be consulted.

In subsequent sections the author deals with "The Earth and its Products" (geology, soil, agriculture), "The Water Cycle" (drainage, water supply, sewerage), "The Town", and "Transport". Much ground has been covered, and Mr. Escritt has taken advice from a long list of specialists in order to make his work authoritative. As a small detail, a question may be asked regarding the use of the word 'hachure' on pages 48 and 50, which is not in accordance with the familiar practice in Great Britain.

A. E. Trumman. 